\title{
Incidence of Mythimna sequax parasitized in wheat crop
}

\author{
Incidência de parasitismo de Mythimna sequax em lavoura de trigo
}

\author{
Orcial Ceolin Bortolotto ${ }^{\text {* }^{*}}$ Ayres de Oliveira Menezes Júnior \\ Adriano Thibes Hoshino ${ }^{I}$ Geraldo Salgado-Neto II
}

\section{ABSTRACT}

This study investigated the natural parasitism of Mythimna sequax Franclemont, 1951, in wheat during the crop season of 2008. In total, 237 larvae were captured, of which 10.12\% were parasitized. The Tachinidae species Winthemia trinitatis (Thompson, 1963), Winthemia tricolor (Wulp, 1890), Lespesia aletiae (Riley, 1879), and Lespesia archippivora Beneway, 1963 are reported for the first time parasitizing the wheat armyworm in Brazil. In addition, two other genus of parasitoids were identified, one Tachinidae Peleteria Robineau-Desvoidy, 1830 and one Ichneumonidae Ophion (Fabricius, 1798). This study reported for the first time four Tachinidae species parasitizing $\boldsymbol{W}$. sequax, and further studies are needed to promote the conservation of these parasitoids in agroecossystem and development biological control programs for management of the wheat armyworm.
\end{abstract}

- NOTE
Key words: natural biological control, wheat pests, Tachinidae, parasitoids.

\section{RESUMO}

Este estudo investigou o parasitismo natural de Mythimna sequax Franclemont, 1951, em uma lavoura de trigo, durante a safra 2008. No total, foram capturadas 237 lagartas, registrando-se um parasitismo de 10,12\%. As espécies de taquinídeos Winthemia trinitatis (Thompson, 1963), Winthemia tricolor (Wulp, 1890), Lespesia aletiae (Riley, 1879) e Lespesia archippivora (Beneway, 1963) são registrados pela primeira vez parasitando a lagarta-do-trigo no Brasil. Adicionalmente, dois gêneros de parasitoides foram identificados, um taquinídeo Peleteria sp. (Robineau-Desvoidy, 1830) e um ichneumonídeo Ophion sp. (Fabricius, 1798). Este estudo registra pela primeira vez a ocorrência de quatro espécies de parasitoides em M. sequax no Brasil, e estudos adicionais são necessários para promover a conservação desses parasitoides no agroecossistema, assim como o desenvolvimento de programas de controle biológico para o manejo da lagarta-do-trigo.
Palavras-chave: controle biológico natural, pragas do trigo, Tachinidae, parasitoides.

Endoparasitoids are one of the main potential natural enemies of Mythimna [Pseudaletia] spp. (GASSEN, 1986) that are able to regulate the pest's seasonal abundance (LAUB \& LUNA, 1992). Development of successful biological control programs requires the knowledge of potential natural enemies that regulate pest populations. In Brazil, some studies have been developed in laboratory conditions (DOETZER \& FOERSTER, 1998; YAMAMOTO et al., 1998; FOERSTER et al., 1999), but scarce information is already available about natural parasitism in agroecosystems. Thus, to assist in the development of better biological programs, it was investigated the occurrence of natural parasitism of Mythimna sequax Franclemont, 1951, in a wheat crop.

The study was carried out in a commercial wheat field during the 2008 crop season. The field is located in Ibiporã $\left(23^{\circ} 17^{\prime} 14^{\prime} \mathrm{S}, 51^{\circ} 05^{\prime} 26^{\prime} \mathrm{W}\right)$, in the northeastern region of the State of Paraná, Brazil. Wheat armyworm occurs annually in this field, thus, allowing this study to be completed.

The larvae were captured using a trap (a floorboard $0.10 \mathrm{~m}$ wide and $0.80 \mathrm{~m}$ long) that was placed in the row spacing of the wheat crop. A total of 40 traps were distributed equidistantly (at $10 \mathrm{~m}$ distance) in the wheat field. Assessments

\footnotetext{
'Departamento de Agronomia, Universidade Estadual de Londrina (UEL), Rodovia Celso Garcia Cid, 86057-970, Londrina, PR, Brasil. E-mail: bortolotto.orcial@gmail.com. *Corresponding author.

IIPrograma de Pós-graduação em Agronomia, Universidade Federal de Santa Maria (UFSM), Santa Maria, RS, Brasil. Received 09.01.14 Approved 04.23.15 Returned by the author 07.23.15 CR-2014-1286.R3
} 
were performed every seven days, starting from the emergence (the first visible leaf) (May, 25 $5^{\text {th }}$ ) until the grain maturation stage (September, $\left.08^{\text {th }}\right)$. Wheat armyworm larvae are nocturnal pests (SPECHT \& CORSEUIL, 2002) that during the day remain probably beneath mulch or soil clods of soil, sheltered from the sunlight. Therefore, collection of M. sequax larvae was carried out daily, at around $14 \mathrm{hs}$, by raising the trap and examining carefully the soil surface for larvae sheltered among the clods of soil. Wheat armyworm larvae were identified by morphological carachteres.

The larvae were counted and placed in a Petri dish (10 cm diameter) and at the laboratory, the specimens were kept under controlled temperature $\left(25 \pm 2^{\circ} \mathrm{C}\right)$, humidity $(60 \pm 20 \%)$, and photophase $(12 \mathrm{~h})$. All specimens were reared on an artificial diet (GREENE et al., 1976) offered ad libitum until the pre pupa stage or parasitoid emergence. The larvae were monitored daily to verify natural death or parasitoid emergence. During the study was report that 10 larvae dead by microorganism (virus and bacteria). All parasitoids were kept in $70 \%$ alcohol and subsequently identified using a stereoscopic microscope. This material has been deposited in the entomological collection of Universidade Federal de Santa Maria.

During the crop season, all of the collected specimens of M. sequax were found in the reproductive stage, between the milky and soft grain stage. In total, 237 larvae were captured, of which $10.12 \%$ ( $n=24$ specimens $)$ were parasitized, mostly by parasitoids from Tachinidae family (Table 1). Among larvae, they were represented in majority $(n=220$ specimes) by larvae between fourth and six instar. In total, four species of parasitoids were identified, and two additional genera were reported, a tachinid (most abundant) and an ichneumonid (Table 1).

In the present study, species of the genus Winthemia (Robineau-Desvoidy, 1830) were the most abundant (Table 1). Similar to the observation in this study, FOERSTER et al. (2001) reported an average of $10 \%$ of parasitism of M. sequax in wheat fields in southern Paraná state. However, unlike the present study, the main parasitoids were hymenopterous species, and only two Tachinidae species, Peleteria robusta (Wiedman, 1830) and Patelloa similis (Townsend, 1927) were detected. The most abundance of Tachinidae in the present investigation can be explained by the larval length $(>1.5 \mathrm{~cm})$ of wheat armyworm captured. So, it was not possible to measure the parasitism in small larvae, and probably the parasitism rate could be different. For example, FOERSTER et al. (2001) reported the wasp Campoletis flavicincta (Ashmead, 1890) parasitizing M. sequax, which act in small larvae $(<1.5 \mathrm{~cm})$ (DEQUECH, et al., 2014). In field, many factors can influence the parasitism rate in wheat armyworm; in some studies carried out in agricultural fields in USA, the level of natural parasitism on Mythimna spp. varied between $2.4 \%$ (MARINO \& LANDIS, 1996) and 38\% (MENALLED et al., 2003), and this differences can occur due climatic factors, local landscape and methodology.

The importance of Winthemia trinitatis (Thompson, 1963) has already been recently reported in Brazilian maize fields parasitizing Spodoptera frugiperda (JE Smith, 1797) (BORTOLOTTO et al., 2014). It indicates that

Table 1 - Parasitoids emerged from Mythimna sequax captured in wheat crop. Ibiporã, PR, crop season of 2008.

\begin{tabular}{llll}
\hline Specie & Number & $\%$ & Stage of emergence \\
\hline Diptera: Tachinidae & - & - & - \\
Winthemia trinitatis & 8 & 33.33 & pupal \\
Winthemia tricolor & 8 & 33.33 & pupal \\
Lespesia archippivora & 2 & 8.33 & larval $\left(6^{\text {th }}\right.$ instar $)$ \\
Lespesia aletiae & 2 & 8.33 & larval $\left(6^{\text {th }}\right.$ instar $)$ \\
Peleteria sp. & 3 & 12.50 & pre-pupal \\
Hymenoptera: Ichneumonidae & - & - & - \\
Ophion sp. & 1 & 4.18 & larval $\left(5^{\text {th }}\right.$ instar $)$ \\
Total & 24 & 100.00 & - \\
\hline
\end{tabular}

Ciência Rural, v.45, n.12, dez, 2015. 
this parasitoid is an important natural enemy of armyworm pests, and additional studies will elucidate the biological parameters of this parasitoid and the potential for its augmentative release in crop fields.

According to SABROSKY (1980), species from the genus Lespesia RobineauDesvoidy, 1863 in the Western Hemisphere are among the largest and most important parasitoids within Tachinidae family, and recently they have been reported as important parasitoids in the Neotropical region. For example, the species L. archippivora has often been recorded in the fall armyworm $\boldsymbol{S}$. frugiperda (DEQUECH et al., 2004; DELFÍN-GONZÁLEZ, 2007). On the other hand, the species $L$. aletiae has a limited distribution, although it has been recorded parasitizing Mythimna unipuncta (Haworth, 1809 ) in the United States (LAUB \& LUNA, 1992). In Brazil, BORTOLOTTO et al. (2014) recently observed both parasitoids in maize fields parasitizing $\boldsymbol{S}$. frugiperda. However, this is the first report of their occurrence in wheat armyworm.

In summary, this is the first report of the natural occurrence of $\boldsymbol{W}$. trinitatis, $W$. tricolor, $\boldsymbol{L}$. aletiae, and $L$. archippivora parasitizing wheat armyworm in Brazil. These results warrant further similar studies of Brazilian agroecosystems, in order to increase knowledge about the potential parasitoids of wheat armyworm, as well as the possibilities in the development of biological control programs against this important pest of many crop grasses.

\section{ACKNOWLEDGMENTS}

The authors are grateful to the Coordenação de Aperfeiçoamento de Pessoal de Nível Superior (CAPES) and to the Conselho Nacional de Desenvolvimento Científico e Tecnológico (CNPq) for providing the scholarships.

\section{REFERENCES}

BORTOLOTTO, O.C. et al. Sugar solution treatment to attract natural enemies and its impact on fall armyworm Spodoptera frugiperda in maize fields. Interciencia, v.39, p.416-421, 2014. Available from: <http://www.interciencia.org/v39_06/416.pdf > . Accessed: Ago. 13, 2014.

DELFÍN-GONZÁLEZ, H. et al. Parasitoids of fall armyworm (Lepidoptera: Noctuidae) from a traditional maize crop in the mexican state of Yucatan. Florida Entomologist, v.90, p.759761, 2007. Available from: <http://journals.fcla.edu/flaent/ article/view/75733/73391>. Accessed: May 22, 2014.
DEQUECH, S.T.B. et al. Ocorrência de parasitóides de Spodoptera frugiperda (J. E. Smith) (Lep., Noctuidae) em lavouras de milho em Cachoeirinha, RS. Ciência Rural, v.34 p.1235-1237, 2004. Available from: <http://www.scielo.br/ pdf/cr/v34n4/a42v34n4.pdf>. Accessed: Feb. 05, 2014. doi: 10.1590/S0103-84782004000400042.

DOETZER, A.K.; FOERSTER, L.A. Efeito do parasitismo por Glyptapanteles muesebecki (Blanchard) no consumo e utilização do alimento por Pseudaletia sequax Franclemont. Anais da Sociedade Entomológica do Brasil, v.27, p.255264, 1998. Available from: <http://www.scielo.br/scielo. php?pid $=$ S0301-80591998000200012\&script $=$ sci_arttext $>$. Accessed: May 22, 2014

FOERSTER, L.A et al. Effect of temperature on the development and progeny production of Glyptapanteles muesebecki (Blanchard) (Hymenoptera: Braconidae) parasitizing larvae of Pseudaletia sequax Franclemont (Lepidoptera: Noctuidae). Anais da Sociedade Entomológica do Brasil, v.28, n.3, p.485-490, 1999. Available from: <http://www.scielo.br/scielo. php script $=$ sci_arttext $\&$ pid $=$ S0301-80591999000300014 $>$. Accessed: Mar. 03, 2014.

FOERSTER, L.A. et al. Parasitóides larvais de Mythimna (Pseudaletia) sequax Franclemont e capacidade de parasitismo de Glyptapanteles muesebecki (Blanchard) em relação ao tempo de exposição, temperatura e densidade de hospedeiros. Acta Biologica do Paraná, v.30, p.139149, 2001. Available from: <http://www.scielo.br/pdf/ne/ v32n3/18764.pdf>. Accessed: Apr. 08, 2014. doi: 10.1590/ S1519-566X2003000300016.

GASSEN, D.N. Parasitos, patógenos e predadores de insetos associados à cultura do trigo. Passo Fundo, Embrapa-CNPT, 1986. 86p. (Embrapa-CNPT, Circular técnica 1)

GREENE, G.L. et al. Velvetbean caterpillar: a rearing procedure and artificial medium. Journal of Economic Entomology, v.69, n.4, p.487-488, 1976. Available from: <http://www. ingentaconnect.com/content/esa/jee/1976/00000069/00000004/ art00020>. Accessed: May 14, 2014.

LAUB C.A.; LUNA J.M. Winter cover crop suppression practices and natural enemies of armyworm (Lepidoptera: Noctuidae) in non-till corn. Environmental Entomology, v.21, p.41-49, 1992, Available from: <http://www.fieldcornipm.ento. vt.edu/ResearchPubs\%20Folder/AW_NE Pub EnvEnt 92.pdf>. Accessed: May 26, 2014

MARINO, P.C.; LANDIS, D.A. Effect of landscape structure on parasitoid diversity in agroecosystems. Ecological Applications, v.6, p.276-284, 1996. Available from: <http:// www.landislab.ent.msu.edu/pdf/Landis\%20 Lab/1996/ Marino\%20\%20and\%20Landis\%201996.pdf>. Accessed: Apr. 23,2014 .

MENALLED, F.D. et al. Temporal variation in the response of parasitoids to agricultural landscape structure. Agriculture. Ecosystems and Environment, v.96, p.2935, 2003. Available from: <http://www.sciencedirect.com/science/article/ pii/S $0167880903000185>$. Accessed: Apr. 21, 2014. doi: 10.1016/S0167-8809(03)00018-5. 
SABROSKY, C.W. A revised key to the neartic species of Lespesia (Diptera: Tachinidae). Annal of Entomological Society of America, v.73, p.63-73, 1980. Available from: $<$ http://www.ingentaconnect.com/content/esa/ aesa/1980/00000073/00000001/art00014>. Accessed: Mar. 28, 2014

SPECHT, A.; CORSEUIL, E. Avaliação populacional de lagartas e inimigos naturais em azevém, com rede de varredura. Pesquisa Agropecuária Brasileira, v.37, n.1, p.1-6, 2002. Available from: <http://www. scielo.br/scielo.php? script $=$ sci arttext\&pid=S0100-
$204 \times 2002000100001 \& 1 \mathrm{ng}=\mathrm{en} \& \mathrm{n} \mathrm{rm}=\mathrm{is} \mathrm{o}>$. Accessed: Mar. 06, 2015. doi: 10.1590/S0100$204 \times 2002000100001$.

YAMAMOTO, A.C. et al. Efeito da temperatura no desenvolvimento de Euplectrus ronnai (Brèthes) (Hymenoptera, Eulophidae) parasitando lagartas de Pseudaletia sequax Franclemont (Lepidoptera: Noctuidae) e impacto do parasitismo no consumo alimentar do hospedeiro. Acta Biologica Paranaense, v.27, p.85-95, 1998. Available from: <http://ojs.c3s1.ufpr.br/ojs2/index.php/acta/article/ view/673>. Accessed: Ago. 08, 2014

Ciência Rural, v.45, n.12, dez, 2015. 